Article

\title{
Hydrogen Sulfide Effects on the Survival of Lactobacilli with Emphasis on the Development of Inflammatory Bowel Diseases
}

\author{
Ivan Kushkevych ${ }^{1, *(1)}$, Věra Kotrsová ${ }^{1}$, Dani Dordević ${ }^{2}\left(\right.$, Leona Buňková $^{3}$, Monika Vítězová ${ }^{1}$ \\ and Amedeo Amedei ${ }^{4}$ (i) \\ 1 Department of Experimental Biology, Faculty of Science, Masaryk University, Kamenice 753/5, 62500 Brno, \\ Czech Republic; vera.kotrsova@ceitec.muni.cz (V.K.); vitezova@sci.muni.cz (M.V.) \\ 2 Department of Plant Origin Foodstuffs Hygiene and Technology, Faculty of Veterinary Hygiene and Ecology, \\ University of Veterinary and Pharmaceutical Sciences, 61242 Brno, Czech Republic; \\ dani_dordevic@yahoo.com \\ 3 The Department of Environmental Protection Engineering, Faculty of Technology, Tomas Bata University in \\ Zlín, 76001 Zlín, Czech Republic; bunkova@utb.cz \\ 4 Department of Experimental and Clinical Medicine, University of Florence, 50134 Florence, Italy; \\ amedeo.amedei@unifi.it \\ * Correspondence: ivan.kushkevych@gmail.com; Tel.: +420-549-495-315
}

Received: 16 October 2019; Accepted: 15 November 2019; Published: 20 November 2019

\begin{abstract}
The gut microbiota is a complex component of humans that depends on diet, host genome, and lifestyle. The background: The study purpose is to find relations between nutrition, intestinal lactic acid bacteria (LAB) from various environments (human, animal intestine, and yogurt) and sulfate-reducing microbial communities in the large intestine; to compare kinetic growth parameters of LAB; and to determine their sensitivity to different concentration of hydrogen sulfide produced by intestinal sulfate-reducing bacteria. Methods: Microbiological (isolation and identification), biochemical (electrophoresis), molecular biology methods (DNA isolation and PCR analysis), and statistical processing (average and standard error calculations) of the results were used. The results: The toxicity of hydrogen sulfide produced by sulfate-reducing bacteria, the survival of lactic acid bacteria, and minimal inhibitory concentrations (MIC) were determined. The measured hydrogen sulfide sensitivity values were the same for $L$. paracasei and L. reuteri (MIC $>1.1 \mathrm{mM}$ ). In addition, L. plantarum and L. fermentum showed also a similar sensitivity (MIC $>0.45 \mathrm{mM}$ ) but significantly $(p<0.05)$ lower than $L$. reuteri and L. paracasei $(1.1>0.45 \mathrm{mM})$. L. paracasei and L. reuteri are more sensitive to hydrogen sulfide than L. fermentum and L. plantarum. L. pentosus was sensitive to the extremely low concentration of $\mathrm{H}_{2} \mathrm{~S}$ (MIC $>0.15 \mathrm{mM}$ ). Conclusions: The Lactobacillus species were significantly sensitive to hydrogen sulfide, which is a final metabolite of intestinal sulfate-reducing bacteria. The results are definitely helpful for a better understanding of complicated interaction among intestinal microbiota and nutrition.
\end{abstract}

Keywords: hydrogen sulfide; toxicity; intestinal microbiome; sulfate-reducing bacteria; lactic acid bacteria; inflammatory bowel disease; ulcerative colitis

\section{Introduction}

One of the main goals of the World Health Organization is the treatment of malnutrition among children under 5 years old. Protective factors against malnutrition are breastfeeding, food, and water safety, the same as these factors play an important role in healthy gut microbiota (GM) [1]. The gut microbiota is a complex component of humans that depends on diet [2], host genome, and lifestyle. 
Increasing data suggest that the GM modulates several host pathways, playing a key role in human physiology and impacting in the development of different pathologic disorders, such as inflammatory bowel diseases (IBD), obesity [3], autism spectrum disorders, stroke, and cancer, especially colorectal cancer [4].

The typical maternal probiotic is lactic acid bacteria (LAB), and the absence of these bacteria leads to inefficient absorption of macro and micronutrients from food, while their absence is associated with diarrhea and pathogens invasion. Studies have started to focus on trials including non-toxic missing microbes and nutrients necessary to restore $\mathrm{LAB}$ and healthy mature anaerobic gut microbiota [1]. The proper functioning of the digestive tract is secured by the LAB presence since lactic acid bacteria represent an integral GM component. The main LABs include Lactococcus sp., Bifidobacterium sp., Lactobacillus sp., Streptococcus sp., Leuconostoc sp., Pediococcus sp., and Enterococcus sp. [5]. This heterogeneous group of bacteria can be found in various environments including human, animals, and plants. It has been confirmed that some probiotic strains have health benefits as they prevent bacterial translocation and gut infections [6].

The final product of LAB fermentative metabolism is lactic acid [7]. Homofermetative LABs are Lactobacillus acidophilus, Streptococcus salivarius, Lactococcus lactis; heterofermentative LABs are Lactobacillus brevis, Lactobacillus fermentum, and Leuconostoc mesenteroides. The heterofermentative products are lactic acid, acetic acid, ethanol, and carbon dioxide [8,9]. Since LAB belong to an acidophilic group, their cultivation has to be done by a medium that includes carbohydrates, amino acids, peptides, vitamins, and nucleic acid derivatives [10].

Different studies observed reduced LAB levels in subjects with inflammatory bowel disease, in particular, ulcerative colitis (UC) [11,12]. However, the main issue in a UC explanation is still the unclear causes of its development. At present, it is explained as a combination of environmental and genetic factors. On the other side, numerous studies have found a certain relation between the occurrence of sulfate-reducing bacteria (SRB), their hydrogen sulfide overproduction, and the UC occurrence [13-17]. Toxic hydrogen sulfide is the final SRB metabolic product since they use sulfate as an electron acceptor $[18,19]$. Sulfate intake is highly dependent on diet, due to its occurrence in the following food commodities: some breads, dried fruits, brassicas, sausages, some beers, ciders, and wines [20]. The whole intestinal microbiome is under the influence of diet, host lifestyle, chemotherapeutic treatment, similar to the complicated relationship between LAB and microorganisms in the intestines [21]. The fluctuations in the gut microbiome can be a trigger and the cause of IBD, such as UC. Studies that include GM investigation and monitoring are very important since it has been confirmed that processes in the intestinal microbiome play an important role in different physiological processes existing in human and animal bodies.

In recent years, there are many types of research dedicated to the antibiotic sensitivity of LAB since these microorganisms are most sensitive to antibiotics and chemotherapy. However, inhibitory concentrations and the mechanism of action of hydrogen sulfide (produced by SRB) on LAB has never been reported and studied before.

The purpose of the study is to find relations between nutrition, intestinal lactic acid bacteria from various environments (human, animal intestine, and yogurt), and sulfate-reducing microbial communities in the large intestine; to compare the kinetic growth parameters of $\mathrm{LAB}$, and to determine their sensitivity to different concentrations of hydrogen sulfide produced by intestinal SRB.

\section{Materials and Methods}

\subsection{Isolation and Identification of Lactic Acid Bacteria}

MRS medium (Sigma-Aldrich, Prague, Czech Republic) was used for the isolation of five LAB species from different environments. In the samples of human and mice feces, yogurt, similar to probiotic pills, were added to the tube with MRS medium, and they were cultured for $24 \mathrm{~h}$ at $37^{\circ} \mathrm{C}$ in a thermostat. The mixed cultures were diluted, after $24 \mathrm{~h}$, and plated on Petri dishes (MRS agar). 
Chosen bacterial colonies were isolated and purified using the streak plate method and stored in the fridge. LAB strains were kept at the Laboratory of Anaerobic Microorganisms of the Department of Experimental Biology at Masaryk University (Brno, Czech Republic). The first step for bacterial identification was microscopic methods. The bacterial cultures were fixed to the microscope slide using a fire flame and then treated with Gram staining. Distilled water was used between each step to wash out a dye residue. The bacterial strains were subjected to a microscopic analysis at $1000 \times$ magnification using a light microscope (Olympus BX50, Olympus Czech Group, Prague, Czech Republic).

\subsection{DNA Isolation and Polymerase Chain Reaction (PCR)}

A commercial kit QIAmp DNA Mini Kit (QIAGEN, catalog number 51304) was used for DNA isolation. Bacterial samples were identified by $16 \mathrm{~S}$ rRNA gene sequencing with primers chosen according to the Weisburg et al., 1991 [22]:

\section{FPL 5' - AGT TTG ATC CTG GCT CAG - 3’ \\ 806R 5' - GGT TAC CTT GTT ACG ACT T - 3'}

Obtained DNA lysates were prepared for the amplification. PCR mixture was prepared by the following protocol: MasterMix $(100 \mu \mathrm{L})$, primer $8 \mathrm{FPL}(100 \mu \mathrm{M})-1.0 \mu \mathrm{L}$, primer $806 \mathrm{R}(100 \mu \mathrm{M})-1.0 \mu \mathrm{L}$, uracil-DNA glycosylase- $-1.0 \mu \mathrm{L}$, deionized water-77.0 $\mu \mathrm{L}$. There was $180 \mu \mathrm{L}$ of PCR mixture, in total. Of the PCR mixture, $18 \mu \mathrm{L}$ was added to the PCR tube. Of DNA lysate, $2 \mu \mathrm{L}$ was added.

\subsection{The Sequence Analysis of $16 S$ rRNA}

Purified amplicons were sequenced, and obtained sequences were compared with known reference strains in the database of the National Center for Biotechnology Information (NCBI) using the basic local alignment search tool (BLAST). The unique ID numbers for each sequence were obtained and saved in GenBank (Lactobacillus pentosus MK736277, L. paracasei MK736278, L. plantarum MK736279, L. fermentum MK736280, and L. reuteri MK736281).

\subsection{Electrophoresis}

Warmed up agarose gel of 1.5\%, including $55 \mu \mathrm{L}$ of GelRed (Sigma-Aldrich, Prague, Czech Republic), was poured to the electrophoresis tray. Loading dye of $0.5 \mu \mathrm{L}$ and $3.5 \mu \mathrm{L}$ of water were mixed with $1 \mu \mathrm{L}$ of the sample. Three $\mu \mathrm{L}$ of the ladder and $5 \mu \mathrm{L}$ of the sample mixtures were loaded to the agarose gel. Electrophoresis was conducted for $60 \mathrm{~min}$ in a Tris-borate-EDTA (TBE) buffer. Agarose gel was run at a voltage of $80 \mathrm{~V}$. The gel was analyzed by G: BOX F3-Gel Imaging (Figure S1). Five $\mu \mathrm{L}$ of primer 8FPL was added to each tube with $5 \mu \mathrm{L}$ of the amplified sample.

\subsection{Bacterial Growth Parameters Determination}

Growth parameters of each strain were calculated using an optical density measurement, and growth curves were created by a Bioscreen C spectrophotometer (Dynex Technologies, Prague, Czech Republic) that included CFU calculation, same as calibration curve creation. The values included in the calculations of individual curves were selected in accordance with the scheme (Figure S2). The growth parameter calculations were done by the following formulas.

Average division rate $(\mathrm{R})$ : the number of generations related to the growth time of the population ( $t=$ time; $X=$ colony forming units per milliliter):

$$
R=\frac{1}{\log 2} \cdot \frac{\log X-\log X_{0}}{t-t_{0}}
$$


Generation time $(\tau)$ : the time required to form one generation of cells (the time between two divisions):

$$
\tau=\log 2 \cdot \frac{t-t_{0}}{\log X-\log X_{0}}
$$

Specific growth rate $(\mu)$ : means the growth rate per unit of the CFU or biomass:

$$
\mu=2.3 \cdot \frac{\log X-\log X_{0}}{t-t_{0}}
$$

Lag time (L): time of the Lag phase where the cells adapt to the environment and the necessary substances are synthesized:

$$
L=t_{k}-t_{e}
$$

$t_{k}$ : time from the start of the experiment to the time of the end of the stationary phase

$t_{e}$ : time of exponential phase, which can be calculated by the formula:

$$
t_{e}=\frac{1}{\log 2} \cdot \tau \cdot\left(\log X-\log X_{0}\right)
$$

\subsection{The Evaluation of Minimal Inhibitory Concentrations (MIC)}

Sodium sulfide was used as the source of the hydrogen sulfide. LAB cultures were cultivated during a $24 \mathrm{~h}$ period in the presence of hydrogen sulfide (Figure S3). One hundred $\mu \mathrm{L}$ of $\mathrm{Na}_{2} \mathrm{~S}$ of various concentrations (from 0.038 to $1.5 \mathrm{mM}$ ) were added to the tubes containing $2 \mathrm{~mL}$ of MRS media. The media was inoculated with $24 \mathrm{~h}$ of LAB cultivation; control samples did not contain $\mathrm{Na}_{2} \mathrm{~S}$. The spectrophotometric method was used for the determination of samples' optical density. Twenty-five $\mu \mathrm{L}$ of the sample diluted by a serial dilution was added on $\frac{1}{4}$ of the MRS agar plate, and the counting of CFU was done after $24 \mathrm{~h}$.

\subsection{Statistical Analysis}

The main statistical parameters $\left(\mathrm{M}-\right.$ mean, $\mathrm{S}_{\mathrm{E}}$-standard error, $\left.\mathrm{M} \pm \mathrm{S}_{\mathrm{E}}\right)$ based on the experimental data were calculated [23]. Statistical significant $(p<0.05)$ differences were measured by principal component analysis (PCA) and cluster analysis. The statistical analysis was carried out by SPSS 20 statistical software (IBM Corporation, Armonk, NY, USA). The plots were built by software package Origin7.0 (Northampton, MA, USA).

\section{Results}

The results are shown in Figure 1. All strains belonged to the Lactobacillus genus, and this was confirmed by sequence analysis of $16 \mathrm{~S}$ rRNA of LAB cultures, isolated from various environments. Nucleotide sequences were identified (Table 1), according to the National Center for Biotechnology Information and the basic local alignment search tool.

Table 1. Lactic acid bacteria (LAB) sequence analysis of $16 \mathrm{~S}$ rRNA.

\begin{tabular}{ccc}
\hline Sources of Isolation. & Species & ID Number in GenBank \\
\hline Human feces 1 & Lactobacillus pentosus & MK736277 \\
Human feces 2 & Lactobacillus paracasei & MK736278 \\
Probiotic supplement & Lactobacillus plantarum & MK736279 \\
Yogurt & Lactobacillus fermentum & MK736280 \\
Mice feces & Lactobacillus reuteri & MK736281 \\
\hline
\end{tabular}




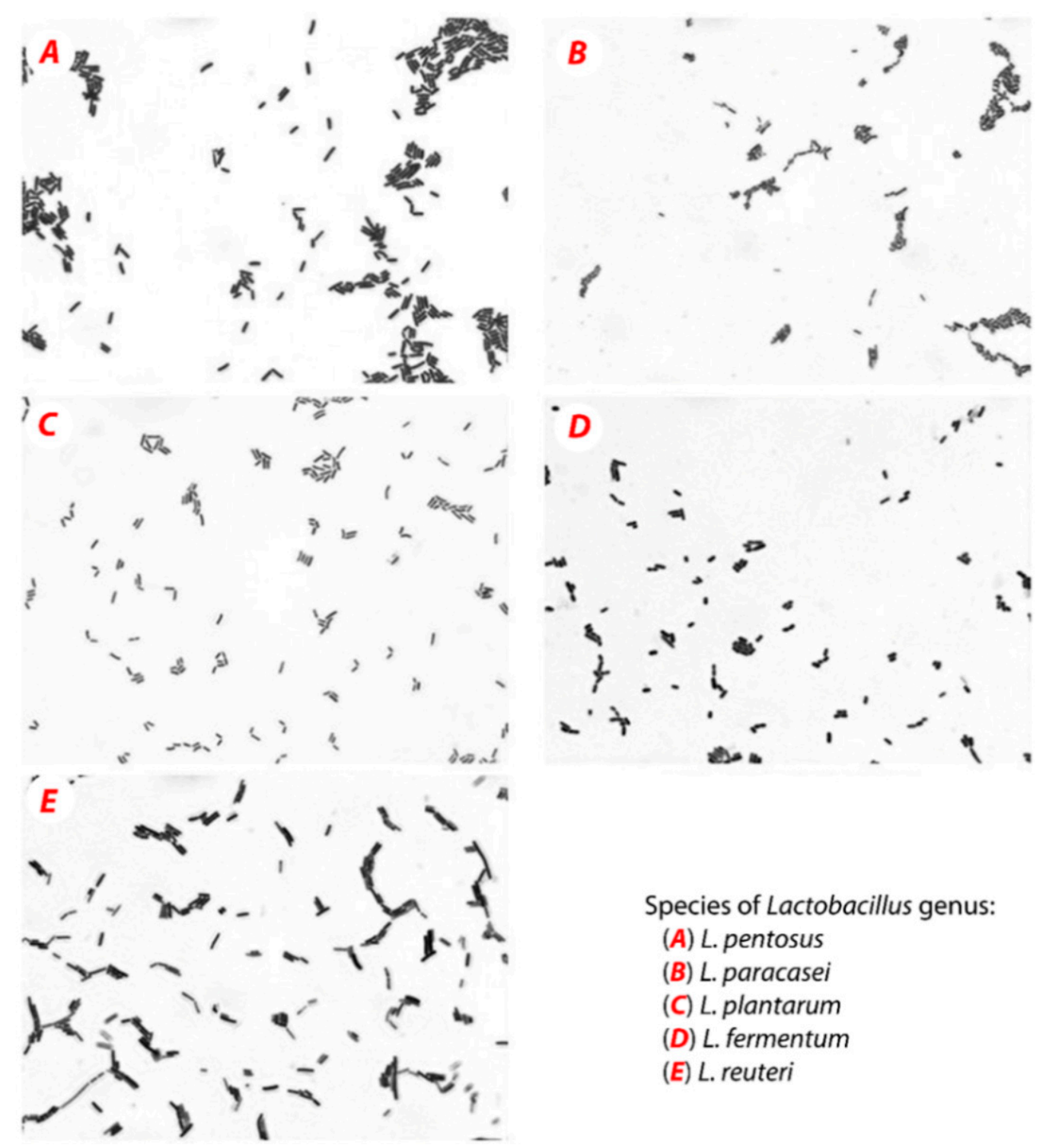

Figure 1. Pure cultures of LAB cells (light microscope, magnification 1000×).

The optical density was measured for $24 \mathrm{~h}$ (Supplement Table S1), and the growth curve shown in Figure 2A was constructed. OD values were used for better orientation and understanding, the same as for the comparison with CFU growth curves (Figure 2B). The calibration curves were used for the conversion of OD to CFU (Table 2 and Supplement Figure S4). CFU value-conditioned growth curves are shown in Supplement Table S2 and Figure 2B. The following growth parameters were calculated: average division ratio, specific growth rate, generation time, and lag time. 

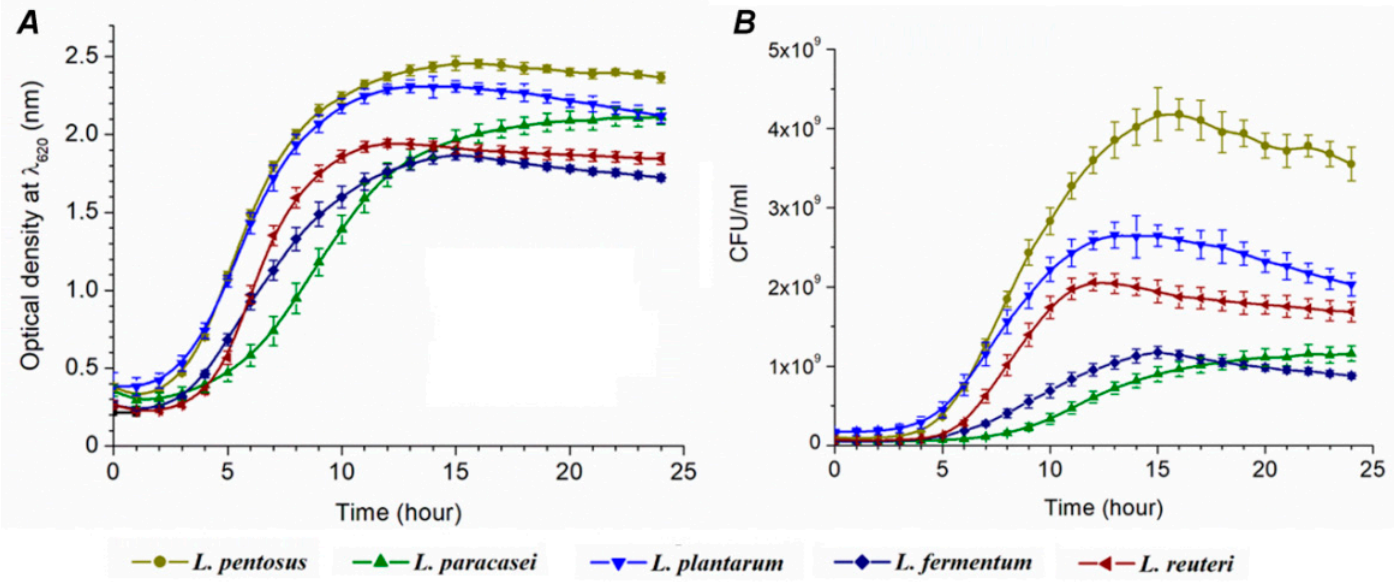

Figure 2. Growth curves of lactic acid bacteria $\left(M \pm S_{E}, n=5\right)$ : data gained by the Bioscreen $C$ spectrophotometer (A) and designed by CFU values (B).

Table 2. The average generation time $(\tau)$, division ratio $(\mathrm{R})$, lag time $(\mathrm{L})$, and specific growth rate $(\mu)$.

\begin{tabular}{ccccc}
\hline Isolates of LAB & $\mathbf{R}\left(\mathbf{h}^{-\mathbf{1}}\right)$ & $\boldsymbol{\tau} \mathbf{( h )}$ & $\boldsymbol{\mu}(\mathbf{h})$ & $\boldsymbol{L} \mathbf{( h )}$ \\
\hline L. pentosus & $0.428 \pm 0.0034$ & $2.338 \pm 0.0188$ & $0.296 \pm 0.0024$ & 5 \\
L. paracasei & $0.243 \pm 0.0230$ & $4.151 \pm 0.3460$ & $0.168 \pm 0.0159$ & 9 \\
L. plantarum & $0.421 \pm 0.0118$ & $2.375 \pm 0.0664$ & $0.292 \pm 0.0082$ & 5 \\
L. fermentum & $0.322 \pm 0.0141$ & $3.116 \pm 0.1310$ & $0.223 \pm 0.0098$ & 7 \\
L. reuteri & $0.650 \pm 0.0172$ & $1.539 \pm 0.0420$ & $0.450 \pm 0.0119$ & 6 \\
\hline
\end{tabular}

The resulting growth parameters are presented in Table 2. The smallest $R$ value was observed for L. paracasei $\left(0.243 \mathrm{~h}^{-1}\right)$ and the highest for L. reuteri $\left(0.650 \mathrm{~h}^{-1}\right)$. It means that L. paracasei needs the shortest time period for cell division in comparison with other species. Conversely, L. reuteri needs the longest time. Significant differences cannot be observed among other species. The longest $\tau$ (generation time) was estimated for L. paracasei $(4.151 \mathrm{~h})$ and the shortest one for L. reuteri $(1.539 \mathrm{~h})$.

Principal component analysis showed that there were no statistically significant $(p<0.05)$ differences between LAB isolates in overall parameters (average generation time, division ratio, and specific growth rate) since only one group can be observed in Figure $3 A$. Cluster analysis showed that L. plantarum and L. pentosus belong to one cluster; they were the most similar according to measured physiological parameters (Figure 3B).
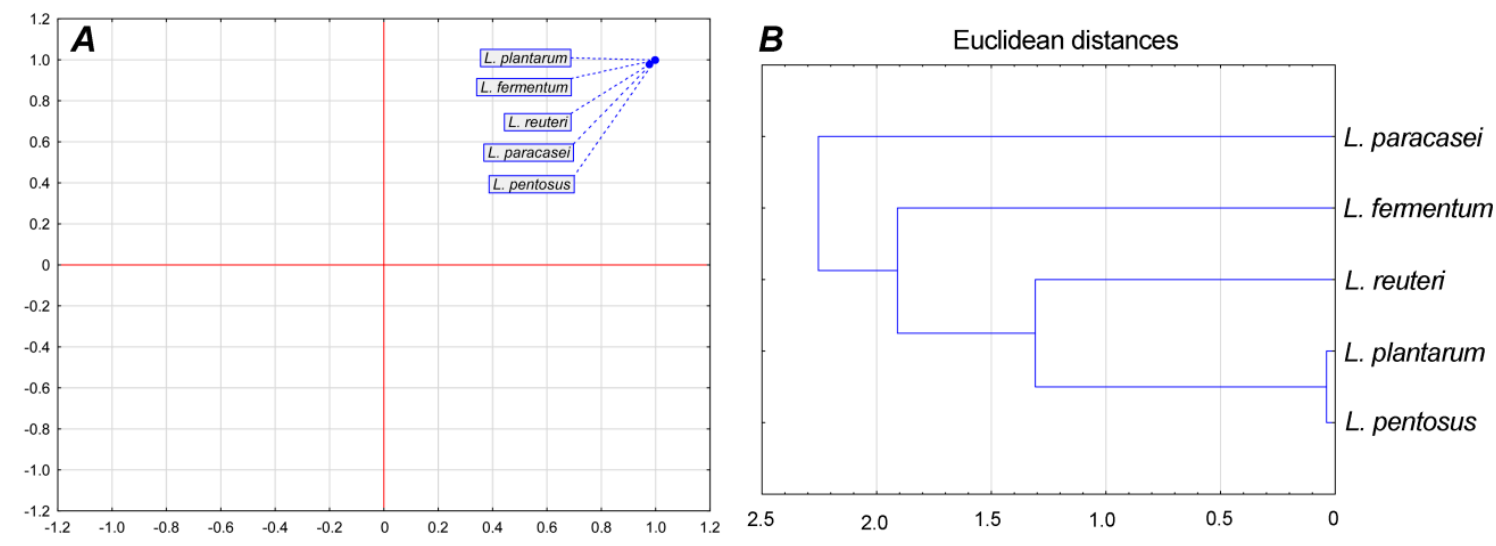

Figure 3. Principal component analysis of growth parameters (A) and cluster analysis (B).

The trend of $\mu$ values (specific growth rate) is in accordance to the trend of $R$ values where the lowest $\mu$ value was observed for $L$. paracasei $(0.168 \mathrm{~h})$ and the highest for L. reuteri $(0.450 \mathrm{~h})$. The longest 
lag time $(9 \mathrm{~h})$ was measured for $L$. paracasei that is in relation to the highest generation time $(4.151 \mathrm{~h})$ within the same species (Supplement Table S4). The percentage of hydrogen sulfide toxicity toward bacterial cells, the same as the percentage of viable cells, is shown in Figure 4.
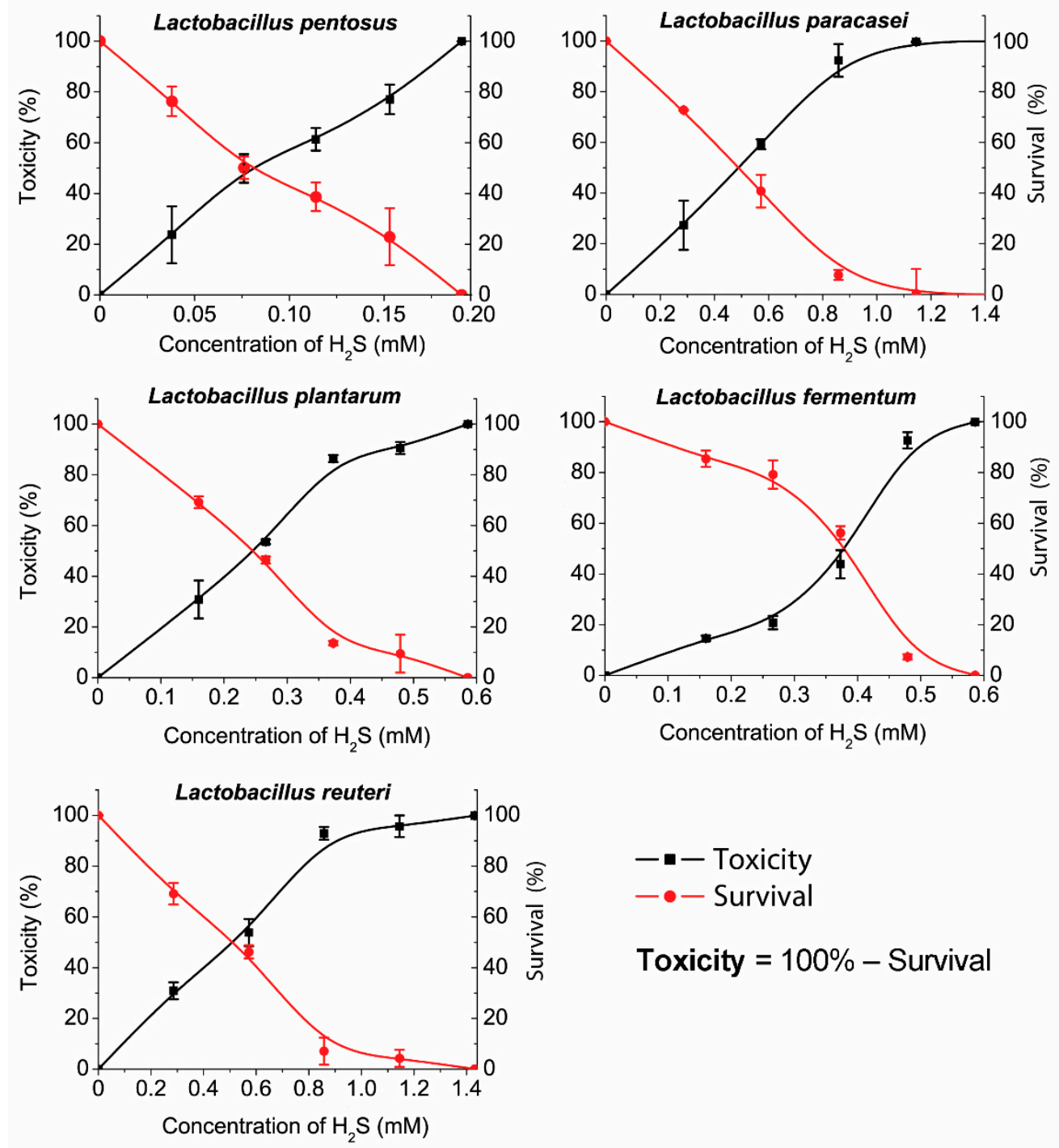

Toxicity $=100 \%-$ Survival

Figure 4. The survival of Lactobacillus species and the toxicity of hydrogen sulfide.

Different sensitivity levels were measured among the different LAB species. Toxicity, survival, and MIC were also determined. The measured hydrogen sulfide sensitivity values were the same for L. reuteri and L. paracasei (MIC > $1.1 \mathrm{mM})$. Also, L. fermentum and L. plantarum showed a similar sensitivity (MIC $>0.45 \mathrm{mM}$ ) but significantly lower than L. reuteri and L. paracasei $(1.1>0.45 \mathrm{mM})$. L. reuteri and L. paracasei are more sensitive to a hydrogen sulfide presence than L. fermentum and L. plantarum. L. pentosus was inhibited at very low concentrations of $\mathrm{H}_{2} \mathrm{~S}$ (MIC $\left.>0.15 \mathrm{mM}\right)$. According to the graph (Figure 3), the toxicity and viability trends of L. pentosus are almost linear, especially in comparison with other species that have shown exponential trends of toxicity and viability. Notably, the data showed that L. pentosus is the most sensitive to the presence of hydrogen sulfide.

The $\mathrm{IC}_{50}$ values that indicate $50 \%$ of dead (or viable) bacteria in the presence of hydrogen sulfide can also be noticed out of plotted graphs. For L. reuteri and L. paracasei, the $\mathrm{IC}_{50}$ is almost the same $\left(\mathrm{IC}_{50}>0.45 \mathrm{mM}\right)$. L. fermentum and L. plantarum had similar MIC values, but their $\mathrm{IC}_{50}$ differ significantly (L. fermentum $>0.4 \mathrm{mM}$; L. plantarum $>0.25 \mathrm{mM}$ ). Out of our results, it can be overviewed 
that all species had a significant trend in relative toxicity growth, similar to the decrease in bacterial survival, though the results obtained for L. fermentum can be considered exceptional.

Isolated LAB from different sources (human feces, probiotic supplement, yogurt, mice feces) had physiologically similar properties, but they have different sensitivity toward hydrogen sulfide.

\section{Discussion}

Lactic acid bacteria are undoubtedly forming an important part of gut microbiota, and proper functioning of the digestive tract depends on their presence. The counts of lactic acid bacteria are significantly reduced in the presence of SRB since they produce toxic hydrogen sulfide. The importance of gut microbiota and the roles of SRB and LAB have been constantly dealt with by many previous studies [24,25]. At the same time, commercially produced probiotic supplements mainly consist of the genus Lactobacillus. The members of the genus Lactobacillus are probably one of the most studied and understood LAB (Heeney et al. (2018)) [26]. The ideal way for this species' isolation is from the host's stool, though they could be significantly changed by the environment of the host's digestive tract. Human feces (L. pentosus, L. paracasei), probiotic supplements (L. plantarum), mice feces (L. reuteri), and yogurt (L. fermentum) were environments used in the isolation research. LAB counts are noticeably reduced during inflammatory bowel diseases, including ulcerative colitis, while the numbers of SRB increase; thus, it resulted in higher $\mathrm{H}_{2} \mathrm{~S}$ concentrations in the intestines.

Our results reveal information about how $\mathrm{H}_{2} \mathrm{~S}$ affects lag phase $(L)$ extension and the time of cell division $(\tau)$. The kinetic parameters of Desulfovibrio piger Vib-7 to $\mathrm{H}_{2} \mathrm{~S}$ were tested in our previous study, indicating that lag phase is doubled in the presence of increased concentrations of $\mathrm{H}_{2} \mathrm{~S}$, while the generation time was extended eight times [18]. Particularly in L. paracasei, in both liquid and solid media, a longer growth time was noticed. L. acidophillus OSU133 growth parameters were tested by Cho et al. (1996) [27]. In their study, the generation time of the strain ranged from 0.3 to $1.2 \mathrm{~h}$ and the lag phase from 1.2 to $6.9 \mathrm{~h}$. Similar results (1.2-1.4 h) were observed by Brizuela et al. (2001) [28]. Gorbach and Goldin (1991) found that the generation time of lactobacilli was one hour [29]. OD and CFU growth curves that differed in terms of growth tendency represent an interesting finding of our study. The increase of microbial biomass indicates that the trend of the growth between species is rather similar. L. pentosus had the largest increase in the biomass for $24 \mathrm{~h}$ (cultivation in tubes and agar plates), while L. paracasei had the smallest one.

The focus of our study was to find the relationship between different concentrations of hydrogen sulfide and lactic acid bacteria (Lactobacillus genus). Some studies also suggest the positive effect of $\mathrm{H}_{2} \mathrm{~S}$ on macro- and microorganisms $[18,19,30,31] . \mathrm{H}_{2} \mathrm{~S}$ produced by bacteria was also found to serve as the defense against antimicrobial compounds, indicating that the cytoprotective effect of $\mathrm{H}_{2} \mathrm{~S}$ is probably a universal mechanism of defense from bacteria to mammals. Reis et al. (1992) found that SRBs are completely inhibited when they are exposed to $\mathrm{H}_{2} \mathrm{~S}$ concentrations higher than $16.1 \mathrm{mM}$ [32]. UC environment is reflected as an increased SRB number and a consequently higher concentration of $\mathrm{H}_{2} \mathrm{~S}$. SRBs are not the only species in the intestines capable of producing $\mathrm{H}_{2} \mathrm{~S}$. The following bacteria can also secrete $\mathrm{H}_{2} \mathrm{~S}$ : Clostridium, Escherichia, Salmonella, Fusobacterium, Klebsiella, Desulfovibrio, and Enterobacter [33]. Clostridia, bifidobacteria, and the Bacteroides fragilis group can degrade sulfated substance, such as colonic mucin, and release free sulfate that can be utilized by SRBs (Gibson et al., 1993) [11]. SRBs can use sulfate as an electron acceptor, an increase in the numbers, to make an intestinal environment appropriate for IBD development.

The important factors affecting the intestinal environment are sulfate consumption, sulfide production, lactate consumption, and acetate accumulation [34-40]. The Desulfovibrio genus is very often present in the intestines and feces of humans and animals with IBD [41-44]. These bacteria in their metabolism use sulfate (terminal electron acceptor) and organic compounds that serve as electron donors [45-47]. Our previous study indicated that Desulfovibrio strains from individuals with colitis were grouped in one cluster by biomass accumulation and sulfide production, and another cluster was formed by the strains from healthy individuals. Acetate produced by SRB can also be 
in synergic interaction with $\mathrm{H}_{2} \mathrm{~S}$, though lactate oxidation represents only minor factors in bowel disease [34]. These conditions may be one of the main UC causes that may lead to a higher incidence of bowel cancer [48-50]. Hydrogen sulfide adversely affects intestinal mucosa and epithelial cells, causes phagocytosis, inhibits the growth of colonocytes, causes the death of intestinal bacteria, and induces hyperproliferation and metabolic abnormalities of epithelial cells [31,51]. The SRB presence is also connected with colon inflammation. Therefore, the integrity of colonocytes depends on hydrogen sulfide concentration $[42,48,49]$.

Other research describing cross-correlation parameters of the SRB metabolic process found out that the strains isolated from people with colitis shifted to the right side of the Y-axis by biomass accumulation, sulfate consumption, lactate oxidation, as well as hydrogen sulfide and acetate production, in comparison with the strains from healthy individuals [34]. It should be stressed that the gut microbiota is a very complex matrix (interactions with clostridia, methanogens, lactic acid bacteria, etc.) and due to it, our study can be limited $[41,52,53]$. Otherwise, it can also be emphasized that a central role in the development of IBD is SRB [31,42-44,54]. Since this bacterial group produces hydrogen sulfide, it can inhibit other microbiota, such as lactic acid bacteria, methanogens, similar to many other intestinal microorganisms [41,54].

A diet high in sulfate ions (preservatives added to food often contain sulfur oxides) leads to an increase in hydrogen sulfide concentration by SRB in rumens. The Western diet contains over $16.6 \mathrm{mmol}$ sulfate/day [20], feces of healthy individuals (approximately 50\%) contain SRB (up to 92\% belong to Desulfovibrio genus) [11,36]. Sulfate polysaccharides such as mucin, chondroitin sulfate, and carrageenan are widely consumed, and they are also good sources of sulfate for SRB [31]. Hydrogen sulfide can also be toxic for its producers. The high toxicity of $\mathrm{H}_{2} \mathrm{~S}$ was measured at concentrations higher than $6 \mathrm{mM}$; the growth was stopped, but 100\% inhibition of metabolic activities was not achieved [19].

Attention must also be paid to the fact that the beneficial effect of hydrogen sulfide formed in the intestine on the general condition of the body, e.g., regulation of arterial pressure, has not been taken into account $[55,56]$. Similarly, the beneficial $\mathrm{H}_{2} \mathrm{~S}$ role in inflammation, which can act as an antioxidant [57].

The species used in industry, such as LAB for yogurt production, are thought to be more resistant to adverse environments. L. plantarum (probiotic supplement) and L. fermentum (yogurt) showed almost the same sensitivity (MIC $>0.45 \mathrm{mM}$ ). It was also perceived that species isolated from the human intestine (from healthy individuals) are more sensitive to $\mathrm{H}_{2} \mathrm{~S}$, but the results of the research showed this in L. pentosus (MIC >0.15 mM) isolated from the human feces. Oppositely, L. paracasei had a lesser sensitivity to $\mathrm{H}_{2} \mathrm{~S}$ exposure (MIC $>1.1 \mathrm{mM}$ ) than L. plantarum (from the probiotic supplement) $(\mathrm{MIC}>0.45 \mathrm{mM})$, meaning that the assumption mentioned above is rejected. The level of hydrogen sulfide in the fecal matter of a healthy human adult ranges from 0.3 to $3.4 \mathrm{mmol} / 1$ [31]. Some areas may have a higher concentration, while others may have lower. The MIC experiment indicates that the level of $\mathrm{H}_{2} \mathrm{~S}$ even in the healthy intestine can be enough for the inhibition of the tested species, especially L. pentosus. The values reported in the publication were measured under conditions that are similar to the intestinal environment (a variety of substrates, hundreds of different bacterial species, the same as bacterial and host metabolites, etc.). It is possible that bacterial species other than lactobacillus may prevail in higher $\mathrm{H}_{2} \mathrm{~S}$ levels while lactobacillus may prevail at lower $\mathrm{H}_{2} \mathrm{~S}$ levels, thus striking a balance. It should be noted that the intestinal microbiota is a very complex system. This research was focused on in an in vitro test with pure cultures of Lactobacillus species only. However, among lactic acid bacteria, the Lactobacillus species are not alone in the intestinal tract. There are also Bifidobacterium, Lactococcus, Streptococcus, and other lactic acid bacterial genera, which are also no less important in the gut. Certainly, future studies should also include a mixed culture in vitro as well as in vivo. These conditions would more simulate the intestinal environment. Also, LAB strains should be tested by binding a specific probe and evaluated by cytometer flow. 


\section{Conclusions}

It is well known that lactic acid bacteria represent a beneficial factor for the host organism. These bacteria, especially their final product of metabolism (lactic acid), play an important role in food fermentation; they fight against pathogenic microorganisms and represent an important element for the whole intestinal ecosystem. Antibiotics or metabolites of other bacteria have an inhibitory effect on LAB. Research has shown that L. pentosus (from human feces) has the highest sensitivity to $\mathrm{H}_{2} \mathrm{~S}$. Conversely, L. paracasei (isolated from human feces) were the most resistant bacteria among other identified Lactobacillus species: L. fermentum (yogurt), L. plantarum (probiotic supplement), and L. reuteri (mice feces). The Lactobacillus species showed significant sensitivity toward hydrogen sulfide. Certainly, the findings of the study will be helpful in future experiments including processes around the intestinal environment affected by inflammatory diseases. The research gives a broader picture of the potentially inhibitory environment toward the presence of health-beneficial LAB strains. Our data can also be connected with previous studies that have found a relationship between reduced numbers of LAB in the presence of Desulfovibrio bacteria leading to higher prevalence of IBD. Especially, the occurrence of ulcer is connected with lower LAB counts that can serve as a signal of processes in the intestines. These processes could be indicators for serious ailments of humans and animals.

Supplementary Materials: The following are available online at http://www.mdpi.com/2218-273X/9/12/752/s1, Figure S1: Electrophoresis gel: samples (1-5), negative control (NC). Bands are in accordance with the presence of the amplified DNA; Figure S2: The typical bacterial growth curve: $\log X, \log X_{0}, t$ and $t_{0}$ mark location of the values for the bacterial growth parameters; $t_{k}$ - the time of the experiment, $t_{e}$ - the time of exponential phase; $L$ is the time of lag phase; Figure S3: LAB cultivation $(24 \mathrm{~h})$ under the influence of $\mathrm{H}_{2} \mathrm{~S}$. After $24 \mathrm{~h}$ the optical density (OD) was determined and, consequently, the reacting mixture was diluted and spread on the MRS agar; Figure S4: The calibration curves used for the conversion of CFU to OD; Table S1: Optical density data measured by Bioscreen $\mathrm{C}$ spectrophotometer $\left(\mathrm{M} \pm \mathrm{S}_{\mathrm{E}}, n=5\right)$; Table S2: The conversion of OD to CFU used to create the calibration curves for Lactobacillus species; Table S3: CFU values calculated by calibration curves equations $\left(\mathrm{M} \pm \mathrm{S}_{\mathrm{E}}, n=5\right)$; Table S4: The minimal inhibitory concentrations for Lactobacillus species

Author Contributions: conceptualization, I.K., V.K., and D.D.; methodology, V.K., I.K., L.B. and M.V.; validation, V.K., M.V., and D.D.; formal analysis, V.K., M.V. and A.A.; investigation, V.K, I.K.; resources, I.K.; data curation, V.K.; writing original draft preparation, I.K., D.D., V.K. and M.V.; writing review and editing, I.K., L.B. and A.A.; visualization, I.K.; supervision, M.V.; project administration, I.K.; funding acquisition, I.K., D.D., L.B. and M.V.

Funding: This research was supported by Grant Agency of the Masaryk University (MUNI/A/0902/2018)

Conflicts of Interest: The authors declare no conflict of interest.

\section{References}

1. Million, M.; Diallo, A.; Raoult, D. Gut microbiota and malnutrition. Microb. Pathog. 2017, 106, $127-138$. [CrossRef] [PubMed]

2. Pagliai, G.; Russo, E.; Niccolai, E.; Dinu, M.; Di Pilato, V.; Magrini, A.; Marcucci, R. Influence of a 3-month low-calorie Mediterranean diet compared to the vegetarian diet on human gut microbiota and SCFA: The CARDIVEG Study. Eur. J. Nutr. 2019, 58, 1-14. [CrossRef] [PubMed]

3. Niccolai, E.; Boem, F.; Russo, E.; Amedei, A. The Gut-Brain Axis in the Neuropsychological Disease Model of Obesity: A Classical Movie Revised by the Emerging Director “Microbiome". Nutrients 2019, 11, 156. [CrossRef]

4. Russo, E.; Bacci, G.; Chiellini, C.; Fagorzi, C.; Niccolai, E.; Taddei, A.; Miloeva, M. Preliminary comparison of oral and intestinal human microbiota in patients with colorectal cancer: A pilot study. Front. Microbiol. 2018, 8, 2699. [CrossRef] [PubMed]

5. Fijan, S. Microorganisms with Claimed Probiotic Properties: An Overview of Recent Literature. Int. J. Environ. Res. Public Health 2014, 11, 4745-4767. [CrossRef] [PubMed]

6. Rayes, N.; Seehofer, D.; Neuhaus, P. Prebiotics, probiotics, synbiotics in surgery - are they only trendy, truly effective or even dangerous? Langenbecks Arch. Surg. 2009, 394, 547-555. [CrossRef]

7. Stilesa, M.; Holzapfel, W. Lactic acid bacteria of foods and their current taxonomy. Int. J. Food Microbiol. 1997, 36, 1-29. [CrossRef] 
8. Sheeladevi, A.; Ramanathan, R. Lactic Acid Production Using Lactic Acid Bacteria under Optimized Conditions. Int. J. Pharm. Biol. Sci. Arch. 2011, 2, 1686-1691.

9. Zotta, T.; Ricciardi, A.; Ianniello, R.G.; Storti, L.V.; Glibota, N.A.; Parente, E. Aerobic and respirative growth of heterofermentative lactic acidbacteria: A screening study. Food Microbiol. 2018, 76, 117-127. [CrossRef]

10. Aguirre, M.; Collins, M. Lactic acid bacteria and human clinical infection. J. Appl. Bacteriol. 1993, 75, 95-107. [CrossRef]

11. Gibson, G.R.; Cummings, J.H.; Macfarlane, G.T. Growth and activities of sulphate-reducing bacteria in gut contents of health subjects and patients with ulcerative colitis. FEMS Microbiol. Ecol. 1991, 86, 103-112. [CrossRef]

12. Cummings, J.H.; Macfarlane, G.T.; Macfarlane, S. Intestinal Bacteria and Ulcerative Colitis. Curr. Issues Intest. Microbiol. 2003, 4, 9-20. [PubMed]

13. Kováč, J.; Vítězová, M.; Kushkevych, I. Metabolic activity of sulfate-reducing bacteria from rodents with colitis. Open Med. 2018, 13, 344-349.

14. Kushkevych, I.; Vítězová, M.; Fedrová, P.; Vochyanová, Z.; Paráková, L.; Hošek, J. Kinetic properties of growth of intestinal sulphate-reducing bacteria isolated from healthy mice and mice with ulcerative colitis. Acta Vet. Brno. 2017, 86, 405-411. [CrossRef]

15. Kushkevych, I.; Fafula, R.; Parak, T.; Bartoš, M. Activity of $\mathrm{Na}^{+} / \mathrm{K}^{+}$-activated $\mathrm{Mg}^{2+}$-dependent ATP hydrolase in the cell-free extracts of the sulfate-reducing bacteria Desulfovibrio piger Vib-7 and Desulfomicrobium sp. Rod-9. Acta Vet. Brno. 2015, 84, 3-12. [CrossRef]

16. Kushkevych, I.V. Activity and kinetic properties of phosphotransacetylase from intestinal sulfate-reducing bacteria. Acta Biochem. Pol. 2015, 62, 1037-1108. [CrossRef]

17. Kushkevych, I.V. Kinetic Properties of Pyruvate Ferredoxin Oxidoreductase of Intestinal Sulfate-Reducing Bacteria Desulfovibrio piger Vib-7 and Desulfomicrobium sp. Rod-9. Pol. J. Microbiol. 2015, 64, 107-114.

18. Kushkevych, I.; Dordević, D.; Kollar, P.; Vítězová, M.; Drago, L. Hydrogen Sulfide as a Toxic Product in the Small-Large Intestine Axis and its Role in IBD Development. J. Clin. Med. 2019, 8, 1054. [CrossRef]

19. Kushkevych, I.; Dordević, D.; Vítězová, M. Toxicity of hydrogen sulfide toward sulfate-reducing bacteria Desulfovibrio piger Vib-7. Arch. Microbiol. 2019, 201, 389-397. [CrossRef]

20. Florin, T.H.; Neale, G.; Goretski, S. Sulfate in food and beverages. J. Food Compos. Anal. 1993, 6, $140-151$. [CrossRef]

21. Ananthakrishnan, A.N. Epidemiology and risk factors for IBD. Reviews Gastroenterology \& Hepatology. Nat. Rev. Gastroenterol. Hepatol. 2015, 12, 205-217.

22. Weisburg, W.; Barns, S.; Pelletier, D.L. 16 S ribosomal DNA amplification for phylogenetic study. J. Bacteriol. 1991, 173, 697-703. [CrossRef] [PubMed]

23. Bailey, N.T.J. Statistical Methods in Biology; Cambridge University Press: Cambridge, UK, 1995.

24. Ng, S.; Shi, H.; Hamidi, N.; Underwood, F.; Tang, W.; Benchimol, E.; Kaplan, G. Worldwide incidence and prevalence of inflammatory bowel disease in the 21st century: A systematic review of population-based studies. Lancet 2017, 390, 2769-2778. [CrossRef]

25. Ndeh, D.; Gilbert, H. Biochemistry of complex glycan depolymerisation by the human gut microbiota. FEMS Microbiol. Rev. 2018, 42, 146-164. [CrossRef]

26. Heeney, D.; Gareau, M.; Marco, M. Intestinal Lactobacillus in health and disease, a driver or just along for the ride? Curr. Opin. Biotechnol. 2018, 49, 140-147. [CrossRef]

27. Cho, H.Y.; Yousef, A.E.; Sastry, S.K. Growth kinetics of Lactobacillus acidophilus under ohmic heating. Biotechnol. Bioeng. 1996, 49, 334-340. [CrossRef]

28. Brizuela, M.; Serrano, P.; Pérez, Y. Studies on Probiotics Properties of Two Lactobacillus Strains. Braz. Arch. Biol. Technol. 2001, 44, 95-99. [CrossRef]

29. Gorbach, S.L.; Goldin, B. Lactobacillus. United States Pat. 1991, 32, 399.

30. Kimura, H. Production and Physiological Effects of Hydrogen Sulfide. Antioxid. Redox Signal. 2014, 20, 783-793. [CrossRef]

31. Rowan, F.E.; Docherty, N.G.; Coffey, J.C.; O'Connell, P.R. Sulphate-reducing bacteria and hydrogen sulphide in the aetiology of ulcerative colitis. Br. J. Surg. 2009, 96, 151-158. [CrossRef]

32. Reis, M.; Almeida, J.; Lemos, P.; Carrondo, M. Effect of hydrogen sulfide on growth of sulfate reducing bacteria. Biotechnol. Bioeng. 1992, 40, 593-600. [CrossRef] 
33. Blachier, F.; Beaumont, B.; Kim, E. Cysteine-derived hydrogen sulfide and gut health: A matter of endogenous or bacterial origin. Curr. Opin. Clin. Nutr. Metab. Care 2019, 22, 68-75. [CrossRef]

34. Kushkevych, I.; Dordević, D.; Vítězová, M.; Kollár, P. Cross-correlation analysis of the Desulfovibrio growth parameters of intestinal species isolated from people with colitis. Biologia 2018, 73, 1137-1143. [CrossRef]

35. Kushkevych, I.; Dordević, D.; Vítězová, M. Analysis of pH dose-dependent growth of sulfate-reducing bacteria. Open Med. 2019, 14, 66-74. [CrossRef] [PubMed]

36. Kushkevych, I.; Dordević, D.; Kollar, P. Analysis of physiological parameters of Desulfovibrio strains from individuals with colitis. Open Life Sci. 2018, 13, 481-488. [CrossRef]

37. Kushkevych, I.; Vítězová, M.; Kos, J.; Kollár, P.; Jampilek, J. Effect of selected 8-hydroxyquinoline2-carboxanilides on viability and sulfate metabolism of Desulfovibrio piger. J. Appl. Biomed. 2018, 16, 241-246. [CrossRef]

38. Kushkevych, I.; Kollar, P.; Suchy, P.; Parak, T.; Pauk, K.; Imramovsky, A. Activity of selected salicylamides against intestinal sulfate-reducing bacteria. Neuroendocrinol. Lett. 2015, 36, 106-113.

39. Kushkevych, I.; Kollar, P.; Ferreira, A.L.; Palma, D.; Duarte, A.; Lopes, M.M.; Bartos, M.; Pauk, K.; Imramovsky, A.; Jampilek, J. Antimicrobial effect of salicylamide derivatives against intestinal sulfate-reducing bacteria. J. Appl. Biomed. 2016, 14, 125-130. [CrossRef]

40. Kushkevych, I.; Kos, J.; Kollar, P.; Kralova, K.; Jampilek, J. Activity of ring-substituted 8-hydroxyquinoline2-carboxanilides against intestinal sulfate-reducing bacteria Desulfovibrio piger. Med. Chem. Res. 2018, 27, 278-284. [CrossRef]

41. Gibson, G.R.; Macfarlane, S.; Macfarlane, G.T. Metabolic interactions involving sulphate-reducing and methanogenic bacteria in the human large intestine. FEMS Microbiol. Ecol. 1993, 12, 117-125. [CrossRef]

42. Loubinoux, J.; Bronowicji, J.P.; Pereira, I.A. Sulphate-reducing bacteria in human feces and their association with inflammatory diseases. FEMS Microbiol. Ecol. 2002, 40, 107-112. [CrossRef] [PubMed]

43. Loubinoux, J.; Mory, F.; Pereira, I.A.; Le Faou, A.E. Bacteremia caused by a strain of Desulfovibrio related to the provisionally named Desulfovibrio fairfieldensis. J. Clin. Microbiol. 2000, 38, 931-934. [PubMed]

44. Loubinoux, J.; Valente, F.M.A.; Pereira, I.A.C. Reclassification of the only species of the genus Desulfomonas, Desulfomonas pigra, as Desulfovibrio piger comb. nov. Int. J. Syst. Evol. Microbiol. 2002, 52, 1305-1308. [PubMed]

45. Kushkevych, I.; Vítězová, M.; Vítěz, T.; Bartoš, M. Production of biogas: Relationship between methanogenic and sulfate-reducing microorganisms. Open Life Sci. 2017, 12, 82-91. [CrossRef]

46. Kushkevych, I.; Vítězová, M.; Vítěz, T.; Kovac, J.; Kaucká, P.; Jesionek, W.; Bartoš, M.; Barton, L. A new combination of substrates: Biogas production and diversity of the methanogenic microorganisms. Open Life Sci. 2018, 13, 119-128. [CrossRef]

47. Kushkevych, I.; Kováč, J.; Vítězová, M.; Vítěz, T.; Bartoš, M. The diversity of sulfate-reducing bacteria in the seven bioreactors. Arch. Microbiol. 2018, 200, 945-950. [CrossRef]

48. Pitcher, M.C.; Cummings, J.H. Hydrogen sulphide: A bacterial toxin in ulcerative colitis? Gut 1996, 39, 1-4. [CrossRef]

49. Blachier, F.; Davila, A.M.; Mimoun, S. Luminal sulfide and large intestine mucosa: Friend or foe? Amino Acids 2010, 39, 335-347. [CrossRef]

50. Beauchamp, R.O.; Bus, J.S.; Popp, J.A.; Boreiko, C.J.; Andjelkovich, D.A.; Leber, P. A critical review of the literature on hydrogen sulfide toxicity. Crc. Crit. Rev. Toxicol. 1984, 13, 25-97. [CrossRef]

51. Grieshaber, M.K.; Völkel, S. Animal adaptations for tolerance and exploitation of poisonous sulfide. Annu. Rev. Physiol. 1998, 60, 33-53. [CrossRef]

52. Černý, M.; Vítězová, M.; Vítěz, T.; Bartoš, M.; Kushkevych, I. Variation in the Distribution of Hydrogen Producers from the Clostridiales Order in Biogas Reactors Depending on Different Input Substrates. Energies 2018, 11, 3270.

53. Kováč, J.; Kushkevych, I. New modification of cultivation medium for isolation and growth of intestinal sulfate-reducing bacteria. In Proceedings of the International PhD Students Conference MendelNet, Brno, Czech Republic, 6-7 November 2019; pp. 702-707.

54. Kotrsová, V.; Kushkevych, I. Possible methods for evaluation of hydrogen sulfide toxicity against lactic acid bacteria. Biointerface Res. Appl. Chem. 2019, 9, 4066-4069.

55. Tomasova, L.; Konopelski, P.; Ufnal, M. Gut bacteria and hydrogen sulfide: The new old players in circulatory system homeostasis. Molecules 2016, 21, 1558. [CrossRef] [PubMed] 
56. Tomasova, L.; Dobrowolski, L.; Jurkowska, H.; Wróbel, M.; Huc, T.; Ondrias, K.; Ufnal, M. Intracolonic hydrogen sulfide lowers blood pressure in rats. Nitric Oxide 2016, 60, 50-58. [CrossRef] [PubMed]

57. Bronowicka-Adamska, P.; Wróbel, M.; Magierowski, M.; Magierowska, K.; Kwiecień, S.; Brzozowski, T. Hydrogen sulphide production in healthy and ulcerated gastric mucosa of rats. Molecules 2017, $22,530$. [CrossRef] [PubMed] 